\title{
Quality of life and family function of parents of children with atten- tion deficit hyperactivity disorder
}

\author{
Samar Azazy ${ }^{1}$, Hebatallah Nour-Eldein ${ }^{1}$, Hend Salama ${ }^{1}$ and Mosleh Ismail ${ }^{1}$
}

DDepartment of Family Medicine, Faculty of Medicine, Suez Canal University, Ismailia City, Egypt (Correspondence to: H. Nour-Eldein: hebanourzo@ hotmail.com).

\begin{abstract}
Background: Attention deficit hyperactivity disorder (ADHD) is a common paediatric neurodevelopmental disorder, with serious impacts on individuals, families and communities. It is associated with cognitive, behavioural, emotional, social and developmental disturbances and impaired academic achievement.
\end{abstract}

Aims: To describe quality of life (QOL) of parents of ADHD children and family function. To determine the relationship between QOL, family function and sociodemographic characteristics.

Methods: This was a cross-sectional study of 125 parents of children with any type of ADHD who were selected by systematic random sampling. The study was conducted between May and December 2015 in the Outpatient Family Medicine Clinic at Suez Canal University Hospital. The World Health Organization Quality of Life-Brief (WHOQOL-BREF) and Adaptability, Participation, Growth, Affection, Resolution (APGAR) questionnaires were used for data collection.

Results: Median physical, psychological and social domain scores were 12, and mean environmental domain score was 11.9. The median scores of perception of health and QOL of the parents were 3.0. Most of the families $(79.2 \%)$ were dysfunctional. Statistically significant relationships were found between all domains and education; physical scores of QOL and gender, employment and income; psychological scores of QOL and residence; environmental scores of QOL and age, income and marital status. Dysfunctional families were likely to be affected by age, gender, physical and psychological domain scores of QOL of parents.

Conclusions: Parents of children with ADHD had average QOL. Most parents had dysfunctional families. Future family intervention studies are recommended.

Keywords: attention deficit hyperactivity disorder, children, family function, parents, quality of life.

Citation: Azazy S; Nour-Eldein H; Salama H; Ismail M. Quality of life and family function of parents of children with attention deficit hyperactivity disorder. East Mediterr Health J. 2018;24(6):579-587. https://doi.org/10.26719/2018.24.6.579

Received: 11/08/16; accepted: 06/08/17

Copyright @ World Health Organization (WHO) 2018. Some rights reserved. This work is available under the CC BY-NC-SA 3.0 IGO license (https:// creativecommons.org/licenses/by-nc-sa/3.o/igo).

\section{Introduction}

Attention deficit hyperactivity disorder (ADHD) is one of the most common neurodevelopmental disorders in children and adolescents. Symptoms of ADHD are associated with disturbances in cognitive, behavioural, emotional, social and developmental function and impaired academic achievements (1). ADHD is a heterogeneous disorder with genetic factors and deficits in brain structure and neuronal functioning and connectivity $(2,3)$.

According to the definition of ADHD in the Diagnostic and Statistical Manual of Mental Disorders 4th Edition (DSM-IV), the prevalence in 22 Arab countries was 1.3$16 \%$. In 2 studies in Egypt, prevalence ranged from $6.5 \%$ among primary school children in grades 3-5 aged 8-10 years to $7.5 \%$ among children aged 4-12 years (4). The prevalence of ADHD based on DSM-V among children aged 6-14 years in Fayoum City, Egypt reached 20.5\%. In western countries, the prevalence ranged from $7.3 \%$ in Italy to $10.6 \%$ in France and the United States of America (5).

The World Health Organization (WHO) defines quality of life (QOL) assesses individuals' perception of their position in life in the context of the culture and value systems in which they live, and in relation to their concerns, standards, goals and expectations (6). Assessment of QOL is important in medical practice to improve the doctor-patient relationship and assess the effectiveness and relative merits of different treatments, as well as in health service evaluation, research and policy-making (7). Parents of children with ADHD report lower levels of QOL compared to parents of healthy children (8).

Family function is defined in the 5 components of the APGAR scale: Adaptability: sharing of resources, and the degree of satisfaction with the received attention; Participation: refers to family communication and joint decision-making on problem solving; Growth: achieves emotional growth owing to the freedom to change roles within the family; Affection: the individual's satisfaction regarding intimate relationships between family members and family interactions; and Resolution: sharing of time and satisfaction with the commitments that family members establish. Family functioning is seriously affected by children with ADHD, especially in families with simultaneous childhood and parental ADHD (9). Dysfunctional families have less than optimal functioning in areas of relationships, communication, 
organization and problem solving (10).

ADHD is a major clinical and public health problem because its consequences for society are enormous in terms of financial cost, stress on families, impact on academic and vocational activities, and negative effect on self-esteem. It is a common neurodevelopmental disorder with a high degree of associated behavioural problems. It has a negative impact on QOL of parents and on family function.

We have not found any data on QOL or family function among parents of children with ADHD in Egypt or other Arab countries. Evaluation of the QOL of parents with children with ADHD and their family function could facilitate future supportive interventions. The aims of the present study were to describe QOL of parents of ADHD children and family function; and to determine the relationship between QOL and family function and sociodemographic characteristics.

\section{Methods}

\section{Study design}

This was a cross-sectional study that was conducted between May and December 2015 at the Child Psychiatry Clinic at Suez Canal University Hospital, Ismailia City, Egypt. The Clinic has a registry of children aged 6-14 years diagnosed with ADHD. Parents of children with ADHD were recruited during their follow-up visits to the Clinic and then they were referred to the Family Practice Clinic where data were collected.

\section{Study participants}

We included parents of children with any type of ADHD (inattention, hyperactivity or their combination) for $>1$ year based on the diagnostic criteria of DSM-IV. The children were diagnosed by a psychiatrist at the Child Psychiatry Clinic and were undergoing treatment. The following were excluded: parents of $>1$ child with $\mathrm{ADHD}$, as this would have caused cumulative effects on QOL; parents of children diagnosed within the past year; and parents who had children with intellectual problems, pervasive developmental disorder, conduct disorder, oppositional defiant disorder or substance abuse.

\section{Sampling and sample size}

We recruited a systematic randomized sample from the clinic registry, which contains 280 children with ADHD who are being followed up in the clinic. Two hundred and fifty children fulfilled the inclusion and exclusion criteria. A sample of 112 parents was calculated based on the formula (11): $n=\left\{\frac{z \sigma}{E}\right\}^{2}$

$Z=1.96$, where $o=$ the estimates of standard deviation (SD) of QOL among parents with children with ADHD $(\sigma=2.7)(8)$; and $E=$ the margin of error $(E=0.5)$, and we allowed for $10 \%$ drop out, so the total sample included 125 parents. The largest SD was selected to ensure an adequate sample size. The records included telephone numbers and addresses of parents, and they were called and invited for interview and follow-up in the clinic.

\section{Questionnaires}

We used 3 structured questionnaires. They were self-administered, but if the parent was illiterate, the questionnaire was administered by S.S. Azazy.

\section{Questionnaire I}

Questionnaire I collected sociodemographic characteristics: gender, age, marital status, education, employment status, residence and perceived satisfaction with income.

\section{Questionnaire II}

Questionnaire II was an Arabic version of World Health Organization Quality of Life-Brief (WHOQOL-BREF). This is the short version of WHOQOL-100 and is recommended for use with time constraints or to minimize the burden on the respondents. It included 26 items; 24 of which covered 4 QOL domains: physical health (7 items), psychological health (6 items), social relationships (3 items) and environment (8 items). Two other items measured overall QOL and general health (12). Items were rated on a 5-point Likert scale (low score of 1 to a high score of 5) with 3 negatively phrased items in Questions 3,4 and 26. SPSS version 20 was used to calculate the mean of each domain score, which was multiplied by 4 to create scores within a range of $4-20$, so as to be directly comparable with scores derived from the WHOQOL-100, which were transformed to a 0-100 scale using the formula (score -4$) \times(100 / 16)$. High scores indicated high QOL (7). The scores were checked and analysed by a statistician. Validity and reliability of the Questionnaire II in an Arab general population were tested and confirmed. The questionnaire was validated using construct validity. Test-retest reliability and internal consistency for the full questionnaire and all domains were conducted with 30 parents and repeated after 2 weeks with Cronbach's $\alpha$ $\geq 0.7$, as in a previous study (13).

\section{Questionnaire III}

Questionnaire III was an Arabic version of the APGAR scale. It was used to assess perceived family function, with the 5 components: adaptability, participation, growth, affection and resolution. There were 3 possible answers (almost never, sometimes and almost always) for each of the 5 questions, with scores varying between 0 and 2 . The total score ranged between 0 and 10 and families were characterized as functional (7-10) or dysfunctional $(\leq 6)$. A dysfunctional family could also be classified as moderately (4-6) or severely $(\leq 3)$ dysfunctional (14). The APGAR questionnaire was previously translated, face validated (15) and tested for internal consistency and test-retest reliability (Cronbach's $\alpha=0.7$ ). The scoring was checked and analysed by a statistician.

\section{Outcome variables}

Four domains of WHOQOL-BREF instrument (physical, psychological, social and environmental) and family function (functional and dysfunctional). 


\section{Ethical consideration}

The study was approved by the Ethics Committee of the Faculty of Medicine, Suez Canal University. It was performed in accordance with the ethical standards laid down in the 1964 Declaration of Helsinki. The research protocol was registered at the University on 14 April 2015. All parents who agreed to participate gave signed informed consent prior to their inclusion in the study. The questionnaires were anonymous and confidentiality of data was preserved.

\section{Statistical analysis}

The data were entered and analysed by small STATA version 12 (statistics and data) and SPSS version 20. Data were tested for normality using the Shapiro-Wilk test. Categorical data were presented in frequencies and percentages. Continuous normally distributed data were presented as mean (SD). Continuous not normally distributed and ordinal data were presented as median and interquartile range. Nonparametric tests were used Wilcoxon rank-sum (Mann-Whitney test) for the relationship between 2 categorical variables and continuous non-normally distributed variables; Kruskal-Wallis test with post hoc multiple comparison using Mann-Whitney tests) for the relationship between 3 categorical variables and continuous non-normally distributed variables; $\chi^{2}$ test to analyse the relationship between categorical variables; and Fisher's exact test in cases of expected cells $<5$. Binomial logistic regression was used to test the effects of sociodemographic variables and 4 domains of WHOQOL-BREF on the likelihood that participants had dysfunctional families. Tests were two-tailed and $P<0.05$ was considered significant and $P<0.017$ for multiple comparisons.

\section{Results}

The study included 125 parents with children with ADHD, with a 100\% response rate. The mean age of the parents was 35.1 years (range 19-57 years). Most of the participants $95(76 \%)$ were aged $<40$ years. Nearly two thirds of the sample were mothers $80(64 \%)$ and had received secondary education $77(61.6 \%)$. More than half of the participants were employed $(n=71 ; 56.8 \%)$ and most of them $(\mathrm{n}=98 ; 78.4 \%)$ had sufficient income. The majority of the sample lived in urban areas $(\mathrm{n}=106 ; 84.8 \%)$ and 122 $(97.6 \%)$ were married and $3(2.4 \%)$ were divorced.

\section{WHOQOL-BREF}

The median scores of physical, psychological and social scores of the participants were 12.0 and the mean score of their environmental domain was 11.9. The median scores of perception of health and QOL of the parents were 3.0 (Table 1).

There was a significant relationship between physical domain of QOL and gender, employment status, income and educational status (Table 2). Women had lower scores than men; unemployed parents had lower scores than employed parents; parents with insufficient income had lower scores than those with sufficient income; and parents who received primary/preparatory education had the highest score. Post hoc comparison revealed that parents with primary or preparatory education had significantly higher scores than illiterate parents $(z=2.50$ $\mathrm{P}=0.016)$, and they had higher scores than those with secondary and higher education $(\mathrm{z}=3.98, P<0.001)$.

There was a significant relationship between the psychological domain of QOL and residence and educational status (Table 2). The scores of parents who lived in urban areas were lower than those who lived in rural areas, and the participants who received primary/ preparatory education had the highest scores. Post hoc multiple comparison revealed that illiterate parents had significantly lower scores than those with primary/ preparatory education $(z=3.60, P<0.001)$, and they had lower scores than those with secondary and higher education $(z=2.99, P=0.003)$. Parents with secondary and higher education had lower scores than those with primary and preparatory education $(z=3.70, P<0.001)$.

There was a significant relationship between the social domain of QOL and educational status (Table 2). The median scores for parents who received secondary/ high education were near to the median scores for those who were illiterate, but lower than the scores for those who received primary/preparatory. Post hoc comparison revealed that illiterate parents had significantly lower scores than those who had received primary and

\begin{tabular}{|c|c|c|c|c|c|c|}
\hline \multirow[b]{2}{*}{ QOL } & \multicolumn{2}{|c|}{$\begin{array}{l}\text { WHOQOL-BREF } \\
\text { raw scores }\end{array}$} & \multicolumn{2}{|c|}{$\begin{array}{c}\text { WHOQOL-BREF } \\
\text { transformed scores }(4-20)\end{array}$} & \multicolumn{2}{|c|}{$\begin{array}{l}\text { WHOQOL-BREF } \\
\text { transformed scores }(0-100)\end{array}$} \\
\hline & Mean (SD) ** & Median (IQR) & Mean (SD) ** & Median (IQR) & Mean (SD) ** & Median (IQR) \\
\hline Physical domain* & $22.1(4.41)$ & $21.0(19.0-24.0)$ & $12.6(2.52)$ & $12.0(10.9-13.7)$ & $53.8(15.8)$ & $50.0(42.9-60.7)$ \\
\hline Psychological domain* & $17.9(4.53)$ & $18.0(16.0-21.0)$ & $11.9(3.03)$ & $12.0(10.7-14.0)$ & 49.5 (18.9) & $50.0(41.7-62.5)$ \\
\hline Social domain* & $9.29(2.55)$ & $9.0(8.0-10.0)$ & $12.4(3.40)$ & $12.0(10.7-13.3)$ & $52.5(21.2)$ & $50.0(41.7-58.3)$ \\
\hline Environmental domain** & $23.8(5.18)$ & $24.0(20.0-27.0)$ & $11.9(2.59)$ & $12.0(10.0-13.5)$ & $49.0(16.2)$ & $50.0(37.5-59.4)$ \\
\hline Perception of health (Q1) & $2.99(0.87)$ & $3.0(2.0-4.0)$ & $2.99(0.87)$ & $3.0(2.0-4.0)$ & $2.99(0.87)$ & $3.0(2.0-4.0)$ \\
\hline Perception of QOL (Q2) & $3.18(1.04)$ & $3.0(2.0-4.0)$ & $3.18(1.04)$ & $3.0(2.0-4.0)$ & $3.18(1.04)$ & $3.0(2.0-4.0)$ \\
\hline
\end{tabular}

**Normally distributed, *not normally distributed data.

$I Q R=$ interquartile range; $Q_{1}$ and $Q 2=$ ordinal variables; $Q O L=$ quality of life; $S D=$ standard deviation; WHOQOL-BREF = World Health Organization $Q$ uality of Life-Brief. 


\begin{tabular}{|c|c|c|c|c|}
\hline \multirow[t]{2}{*}{ Variable } & Physical domain & $\begin{array}{l}\text { Psychological } \\
\text { domain }\end{array}$ & Social domain & $\begin{array}{l}\text { Environmental } \\
\text { domain }\end{array}$ \\
\hline & Median (IQR) & Median (IQR) & Median (IQR) & Median (IQR) \\
\hline \multicolumn{5}{|l|}{ Age (years) } \\
\hline$<40$ & $12.0(10.9-14.9)$ & $12.0(10.8-14.8)$ & $12.0(10.7-14.7)$ & $12.5(10.0-14.0)$ \\
\hline$\geq 40$ & $12.0(11.7-13.7)$ & $12.0(11.3-13.3)$ & $12.0(10.7-13.3)$ & $11.0(10.0-11.5)$ \\
\hline$z$ & 0.372 & 0.035 & 0.8 & 3.40 \\
\hline$P$ & 0.708 & 0.972 & 0.424 & $0.001^{*}$ \\
\hline \multicolumn{5}{|l|}{ Gender } \\
\hline Female & $11.7(10.3-12.6)$ & $12.0(10.7-14.7)$ & $12.0(10.7-14.7)$ & $11.8(10.0-14.0)$ \\
\hline Male & $13.7(12.0-14.6)$ & $12.0(11.3-13.7)$ & $12.0(9.33-13.3)$ & $12.0(10.8-12.8)$ \\
\hline$z$ & 3.93 & 0.116 & 1.08 & 0.023 \\
\hline$P$ & $<0.001^{*}$ & 0.908 & 0.279 & 0.981 \\
\hline \multicolumn{5}{|l|}{ Employment status } \\
\hline Employed & $12.6(12.0-13.7)$ & $12.0(11.3-14.0)$ & $13.3(10.7-14.7)$ & $12.0(10.0-13.5)$ \\
\hline Unemployed & $11.4(10.3-13.1)$ & $11.3(09.3-12.7)$ & $10.7(10.7-13.3)$ & $9.00(11.0-14.0)$ \\
\hline$z$ & 2.71 & 1.8 & 1.81 & 1.31 \\
\hline$P$ & $0.007^{*}$ & 0.071 & 0.070 & 0.188 \\
\hline \multicolumn{5}{|l|}{ Income } \\
\hline Sufficient & $12.0(11.4-14.3)$ & $12.0(10.7-14.7)$ & $12.7(10.7-14.7)$ & $12.5(10.5-13.5)$ \\
\hline Insufficient & $10.9(10.3-12.0)$ & $11.3(10.0-12.7)$ & $10.7(10.7-12.0)$ & $10.0(8.50-11.5)$ \\
\hline$z$ & 2.32 & 1.69 & 1.71 & 3.36 \\
\hline$P$ & $0.021^{*}$ & 0.091 & 0.086 & $0.001^{*}$ \\
\hline \multicolumn{5}{|l|}{ Residence } \\
\hline Rural & $13.1(12.0-15.4)$ & $12.7(12.7-14.7)$ & $13.3(10.7-17.3)$ & $11.0(11.0-14.0)$ \\
\hline Urban & $12.0(10.7-13.7)$ & $11.3(10.7-13.5)$ & $12.0(10.7-13.3$ & $12.0(10.0-13.5)$ \\
\hline$z$ & 1.93 & 2.65 & 1.78 & 0.207 \\
\hline$P$ & 0.054 & $0.008^{*}$ & 0.075 & 0.836 \\
\hline \multicolumn{5}{|l|}{ Marital status } \\
\hline Married & $12.0(10.7-13.7)$ & $12.0(10.7-14.0)$ & $12.0(10.7-13.7)$ & $12.0(10.0-13.5)$ \\
\hline Divorced & $10.9(10.9-10.9)$ & $11.3(11.3-11.3)$ & $10.7(10.7-10.7)$ & $8.0(8.0-8.0)$ \\
\hline$z$ & 1.50 & 0.704 & 1.30 & 2.67 \\
\hline$P$ & 0.125 & 0.503 & 0.211 & $0.002^{*}$ \\
\hline \multicolumn{5}{|l|}{ Educational status } \\
\hline Illiterate/read and writeı & $12.6(9.1-13.7) 1<2^{* *}$ & $9.33(4.0-11.3) 1<2,3^{* *}$ & $10.7(4.0-12.0) 1<2,3^{* *}$ & $9.0(8.0-9.0) 1<2,3^{* *}$ \\
\hline Primary/preparatory education 2 & $17.7(12.1-17.7) 2>1,3^{* *}$ & $16.7(12.7-16.7) 2>1,3^{* *}$ & $13.3(12.0-18.3) 2>1,3^{* *}$ & $14.0(11.0-15.5) 2>1,3^{* *}$ \\
\hline Secondary and high education3 & $12.0(10.9-13.7) 3<2^{* *}$ & $12.0(10.7-14.0) 3<2^{* *}$ & $12.0(10.7-14.7) 3<2^{* *}$ & $12.0(10.0-13.5) 3<2^{* *}$ \\
\hline $\mathrm{H}$ & 15.9 & 22.7 & 10.0 & 19.0 \\
\hline$P$ & $0.001^{*}$ & $<0.001^{*}$ & $0.007^{*}$ & $<0.001^{*}$ \\
\hline
\end{tabular}

*Statistically significant difference $(P<0.05)$; **Statistically significant difference for multiple comparison $(P<0.017)$.

$z=2$-sample Wilcoxon rank-sum test (Mann-Whitney test).

$\mathrm{H}=$ Kruskal-Wallis test

1,2,3Post hoc analysis using Mann-Whitney tests.

$I Q R=$ interquartile range; $Q O L=$ quality of life; WHOQOL-BREF = World Health Organization Quality of Life-Brief.

preparatory education $(\mathrm{z}=3.13, P=0.001)$ and lower scores than those with secondary and higher education $(z=2.25, P=0.025)$. Parents who had received primary and preparatory education had higher scores than those with secondary and higher education $(z=2.03, P=0.042)$.

There was a significant relationship between the environmental domain of QOL and age, income, marital status and educational status (Table 2). The scores of parents aged $\geq 40$ years were lower than those of parents aged $<40$ years. The scores of parents with insufficient income were lower than those of parents with sufficient income. Divorced parents had lower scores than married 
parents. Parents who received primary/preparatory education had the highest scores. Post hoc comparison revealed that illiterate parents had significantly lower scores than those who had received primary and preparatory education $(\mathrm{z}=3.78, \mathrm{P}<0.001)$, and lower scores than those who had received secondary and higher education $(\mathrm{z}=3.69, \mathrm{P}=0.001)$. Parents who had received secondary and higher education had lower scores than those who had received a primary or preparatory education $(z=2.19, P=0.028)$.

\section{Family function}

Ninety-nine (79.2\%) parents reported dysfunctional families [32 (25.6\%) severe and $67(53.6 \%)$ mild] and $26(20.8 \%)$ reported functional families. There was a significant relationship between family function and age and area of residence (Table 3). Significantly more parents of dysfunctional families were aged $<40$ years. Significantly more dysfunctional families lived in urban areas. There was no significant relationship between family function and gender, educational status, employment status, income sufficiency or marital status.

There was a significant relationship between family function and the psychological domain of QOL (Table 4). The score of the psychological domain of QOL was significantly higher in functional families. There was no significant relationship between family function and the physical, social and environmental domains of QOL.

Age, gender and psychological score of QOL were significant independent negative predictors of dysfunctional families (Table 5). Social and environmental scores were nonsignificant negative predictors of dysfunctional families. Conversely, physical score of QOL was a significant independent positive predictor of a dysfunctional family. Employment status, income insufficiency and rural residence were nonsignificant positive predictors of dysfunctional families. The variables in the regression model predicted $47.5 \%$ of variability in dysfunctional families' scores as indicated by the Nagelkerke $R^{2}$.

\section{Discussion}

Four domains of WHOQOL-BREF, physical, psychological, social and environmental, were studied and their median scores were average. Also the perception of health and QOL of the parents was also around the middle

\begin{tabular}{|c|c|c|c|c|c|c|}
\hline \multirow[t]{3}{*}{ Variable } & \multicolumn{4}{|c|}{ Family function } & \multirow[t]{3}{*}{$\chi^{2}$} & \multirow[t]{3}{*}{ P-value } \\
\hline & \multicolumn{2}{|c|}{$\begin{array}{l}\text { Functional } \\
(\mathrm{n}=26)\end{array}$} & \multicolumn{2}{|c|}{$\begin{array}{l}\text { Dysfunctional } \\
\quad(\mathbf{n}=99)\end{array}$} & & \\
\hline & No. & $\%$ & No. & $\%$ & & \\
\hline \multicolumn{7}{|l|}{ Age (years) } \\
\hline$<40$ & 11 & 42.3 & 84 & 84.9 & \multirow{2}{*}{20.4} & \multirow{2}{*}{$0.001^{*}$} \\
\hline$\geq 40$ & 15 & $57 \cdot 7$ & 15 & 15.1 & & \\
\hline \multicolumn{7}{|l|}{ Gender } \\
\hline Female & 16 & 61.5 & 64 & 64.7 & \multirow{2}{*}{0.09} & \multirow{2}{*}{0.7} \\
\hline Male & 10 & 38.5 & 35 & $35 \cdot 3$ & & \\
\hline \multicolumn{7}{|l|}{ Educational status } \\
\hline Illiterate/read and write & 3 & 11.5 & 5 & 5.05 & \multirow{4}{*}{$\begin{array}{l}\text { Fisher's } \\
\text { exact }\end{array}$} & \multirow{4}{*}{0.6} \\
\hline Primary/preparatory education & 3 & 11.5 & 9 & 9.09 & & \\
\hline Secondary school education & 15 & 57.7 & 62 & 62.6 & & \\
\hline High education & 5 & 19.3 & 23 & 23.2 & & \\
\hline \multicolumn{7}{|l|}{ Employment status } \\
\hline Employed & 13 & 50 & 58 & 58.6 & \multirow{2}{*}{0.6} & \multirow{2}{*}{0.4} \\
\hline Unemployed & 13 & 50 & 41 & 41.4 & & \\
\hline \multicolumn{7}{|l|}{ Income } \\
\hline Perceived as sufficient & 20 & 76.9 & 78 & 78.8 & \multirow{2}{*}{0.04} & \multirow{2}{*}{0.8} \\
\hline Perceived as insufficient & 6 & 23.1 & 21 & 21.2 & & \\
\hline \multicolumn{7}{|l|}{ Residence } \\
\hline Rural & 10 & 38.5 & 9 & 9.09 & \multirow{2}{*}{13.8} & \multirow{2}{*}{$0.001^{*}$} \\
\hline Urban & 16 & 61.5 & 90 & 90.9 & & \\
\hline \multicolumn{7}{|l|}{ Marital status } \\
\hline Married & 26 & 100 & 96 & 96.9 & \multirow{2}{*}{$\begin{array}{l}\text { Fisher's } \\
\text { exact }\end{array}$} & \multirow{2}{*}{0.4} \\
\hline Divorced & 0 & 0 & 3 & 3.03 & & \\
\hline
\end{tabular}

*Statistically significant difference ( $\mathrm{P}$-value $<0.05)$. 


\begin{tabular}{|c|c|c|c|c|c|}
\hline \multirow[t]{2}{*}{ Variable } & & \multicolumn{2}{|c|}{ Family function } & \multirow{2}{*}{$\begin{array}{l}\text { Wilcoxon } \\
\text { rank-sum test }\end{array}$} & \multirow[t]{2}{*}{$P$} \\
\hline & & $\begin{array}{l}\text { Functional } \\
(n=26)\end{array}$ & $\begin{array}{l}\text { Dysfunctional } \\
\quad(n=99)\end{array}$ & & \\
\hline Physical & Median (IQR) & $12.0(10.9-13.7)$ & $12.0(10.9-14.3)$ & $\mathrm{z}=0.11$ & 0.9 \\
\hline Psychological & Median (IQR) & $12.7(11.3-14.8)$ & $12.0(10.0-14.0)$ & $\mathrm{z}=2.2$ & $0.03^{*}$ \\
\hline Social & Median (IQR) & $12.0(10.67-14.0)$ & $12.0(10.7-13.3)$ & $\mathrm{z}=0.75$ & 0.5 \\
\hline Environmental & Median (IQR) & $11.3(11.0-13.0)$ & $12.0(10.0-13.5)$ & $z=0.38$ & 0.7 \\
\hline
\end{tabular}

*Statistically significant difference $(\mathrm{P}<0.05)$.

$z=2$-sample Wilcoxon rank-sum test (Mann-Whitney test).

$\mathrm{IQR}=$ interquartile range.

scores. Most of the participants had dysfunctional families based on APGAR scale.

All the scores of the WHOQOL-BREF domains were lower than in a comparative study by Xiang et al. in Hong Kong (8), which compared QOL of 77 parents of children with ADHD with QOL of the general population. Although the children in the current study were under treatment, QOL of their parents was lower than in the study by Kim et al. in Korea (16). They studied 75 children with ADHD and their parents to assess parental QOL and depressive mood following methylphenidate treatment of their children. The decrease in parental depression scores from baseline to 8 weeks was significantly associated with increases in the domain scores of WHOQOL-BREF. The lower QOL of parents in the current compared with previous studies could be related to differences in socioeconomic status, selection criteria of the participants, or treatment method or compliance. We found partial agreement with other studies that used different tools for assessment of QOL, such as the case-control study by Hadi et al. in the Islamic Republic of Iran (17), in which 100 mothers of children with ADHD scored lower than the control group for most of the dimensions of the Health-Related Quality of Life Scale.

All 4 domain scores of WHOQOL-BREF in the current study were significantly higher in parents who had received primary/preparatory education compared with other levels of education. Significantly lower physical domain scores were found among mothers, unemployed parents and those with insufficient income, compared with fathers, employed parents and those with sufficient income. Psychological domain scores of the parents were lower among those who lived in urban rather than rural areas, which could have been due to other stressful situations in urban areas. Environmental domain scores were lower among parents aged $\geq 40$ years, those with insufficient income and divorced parents, compared with parents aged $<40$ years, those with sufficient income and married parents. Most of these relationships could be explained by the lower socioeconomic status of the parents in $\geq 1$ of the studied categorical variables.

It was found that $79.2 \%$ of families in the current study were dysfunctional. This was consistent with another study that assessed the family function of 47 Norwegian fathers and 217 mothers of children with ADHD using the Family Assessment Device (FAD) (18). This study found that parents with a child with ADHD had poorer family function compared to others who did not have a child with ADHD. Our results of family dysfunction are congruent with another study that used the FAD questionnaire (10).

\begin{tabular}{|c|c|c|c|c|c|c|}
\hline & \multirow[t]{2}{*}{ B } & \multirow[t]{2}{*}{ Wald } & \multirow[t]{2}{*}{$\mathbf{P}$} & \multirow[t]{2}{*}{ OR } & \multicolumn{2}{|c|}{$95 \%$ CI for OR } \\
\hline & & & & & Lower & Upper \\
\hline Age & -0.080 & 5.37 & $0.021^{*}$ & 0.923 & 0.862 & 0.988 \\
\hline Gender (females) & -2.66 & 4.89 & $0.027^{*}$ & 0.070 & 0.007 & 0.739 \\
\hline Employment status (unemployed) & 1.38 & 2.02 & 0.155 & 3.979 & 0.592 & 26.7 \\
\hline Income (insufficient) & 0.592 & 0.502 & 0.478 & 1.807 & 0.352 & 9.28 \\
\hline Residence (rural) & 1.59 & 2.60 & 0.107 & 4.882 & 0.710 & 33.6 \\
\hline Physical scores & 0.882 & 14.9 & $<0.001^{*}$ & 2.415 & 1.54 & 3.78 \\
\hline Psychological scores & -0.802 & 7.785 & $0.005^{*}$ & 0.449 & 0.255 & 0.788 \\
\hline Social scores & -0.096 & 0.487 & 0.485 & 0.909 & 0.694 & 1.19 \\
\hline Environmental scores & -0.139 & 0.445 & 0.505 & 0.871 & 0.579 & 1.31 \\
\hline Constant & 4.67 & 2.529 & 0.112 & 106.475 & & \\
\hline
\end{tabular}

*Statistically significant difference $(P<0.05)$.

$\chi^{2}(9)=45.4, P<0.001 ;$ Model summary: -2 log likelihood $=82.5 ;$ Cox \& Snell $R^{2}=0.304 ;$ Nagelkerke $R^{2}=0.475$.

$\mathrm{CI}=$ confidence interval $; \mathrm{OR}=$ odds ratio. 
It suggested that parents of children with ADHD have difficulty with family cohesiveness and organization. Our results agree partially with a study in the Islamic Republic of Iran that assessed marital satisfaction among 200 parents of children with ADHD and 200 controls using the Evaluation and Nurturing Relationship Issues, Communication and Happiness (ENRICH) questionnaire (19). It showed that parents of children with ADHD had a lower level of marital satisfaction. Our results are also similar to another Iranian study (20) that used the FAD questionnaire and Chulalongkorn Family Inventory on 30 families of children with ADHD and 30 control families. The families of children with ADHD were less healthy in function than the controls were. One explanation is that parents of children with ADHD have problems with child interaction and experience emotional stress, distress and exhaustion. When the child does not respond to ordinary parental requests, stress can rise sharply, which can affect family function. We found that fathers were less likely to report dysfunctional families than mothers were. Increasing age and psychological scores of QOL were associated with a reduced likelihood of dysfunctional families. Increased scores for the physical domain of QOL were associated with increased likelihood of dysfunctional families. Our results are congruent with the study by Moen et al. (18), who also found that increasing age was associated with better family function, although gender was not a predictor. However, Foley concluded that socioeconomic status is not protective against family dysfunction (10). The difference between these studies could be related to the different predictors studied and family function questionnaires used.

\section{Strength and limitations}

This study could be one of the first to investigate parental QOL and family function of children with ADHD in Egypt. Inferential statistics and discussion were based on WHOQOL transformed 4-20 scores to facilitate comparison with other studies. Most studies have used the FAD questionnaire for assessment of family function, which is not exactly comparable with APGAR score. We did not assess the different treatment methods among the children in our study. Outcome variables were not compared with controls and could have been affected by factors other than sociodemographic characteristics, such as disease characteristics. The results cannot be generalized to other parents of children with ADHD because the study was hospital based and only represents parents of children who sought advice or treatment.

\section{Conclusion}

Parents of children with ADHD had average QOL and the majority of them perceived family dysfunction despite all their children receiving treatment. There was a significant relationship between some sociodemographic characteristics and each of the 4 domains of QOL. There was increased likelihood of having dysfunctional families that were reported by mothers and increasing physical scores of QOL, while there was a reduction in likelihood of having dysfunctional families with increasing age and better psychological scores of QOL. Assessment of QOL and family function is recommended in future supportive interventions in families of children with ADHD.

\section{Acknowledgements}

The research team would like to acknowledge the cooperation of psychiatry and family medicine clinic teams and the parents who accept to participate in the study.

Funding: None.

Competing interests: None declared.

\section{Qualité de vie et fonctionnement familial des parents d'enfants souffrant d'un trouble de déficit de l'attention avec hyperactivité}

\section{Résumé}

Contexte : Le trouble de déficit de l'attention avec hyperactivité (TDHA) constitue un trouble neuro-développemental courant de l'enfant ayant une grave incidence sur les individus, les familles et les communautés. Il est associé à des troubles cognitifs, comportementaux, émotionnels, sociaux et développementaux, ainsi qu'à une baisse des résultats scolaires.

Objectifs : Fournir une description de la qualité de vie des parents d'enfants atteints d'un TDHA, ainsi que de leur fonctionnement familial. Déterminer la relation entre la qualité de vie, le fonctionnement familial et les caractéristiques socio-démographiques.

Méthodes : Il s'agissait d'une étude transversale menée auprès de 125 parents d'enfants souffrant de différents types de TDHA, sélectionnés par échantillonnage aléatoire systématique. L'étude a été conduite entre mai et décembre 2015 dans la clinique de consultations externes en médecine familiale du centre hospitalier universitaire du Canal de Suez. Le questionnaire de l'OMS sur la qualité de vie dans sa version abrégée et le score d'Apgar (apparence, pouls, grimace, activité, respiration) ont été utilisés pour recueillir les données.

Résultats : Les scores médians concernant les domaines physique, psychologique et social étaient de 12, et le score moyen du domaine environnemental était de 11,9. Les scores médians de la perception de la santé et de la qualité de vie de ces 
parents étaient de 3,0. La plupart des familles (79,2 \%) étaient dysfonctionnelles. Des liens statistiquement significatifs ont été trouvés entre tous les domaines et l'éducation ; entre les scores de la qualité de vie portant sur la condition physique et le sexe, l'emploi et les revenus ; entre les scores de la qualité de vie portant sur l'état psychologique et le lieu d'habitation ; et entre les scores de la qualité de vie liés à l'environnement et l'âge, les revenus et la situation maritale. Les familles dysfonctionnelles étaient susceptibles d'être affectées par les scores de la qualité de vie des domaines portant sur l'âge, le sexe, et la condition physique et psychologique des parents.

Conclusion: Les parents d'enfants atteints d'un TDHA avaient une qualité de vie moyenne. La plupart des parents venaient de familles dysfonctionnelles. Des études portant sur les interventions familiales sont recommandées à l'avenir.

$$
\begin{aligned}
& \text { جودة الحياة والوظيفة العائلية لآباء الأطفال المصابين باضطر اب قصور الانتباه وفرط الحركة } \\
& \text { سمر عزازي، هبة الله نور الدين، هند سلامة، مصلح إسماعيل }
\end{aligned}
$$

الخلفية: إن اضطراب قصور الانتباه وفرط الحركة هو اضطراب عصبي نموي شائع بين الأطفال، وله آثار خطيرة على الأفر ادو الأسر و المجتمعات.

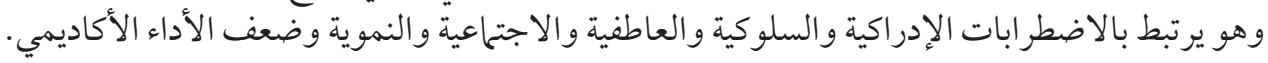

الأهداف: وصف جودة الحياة والوظيفة العائلية لآباء الأطفال المصابين بقصور الانتباه وفرط الحركة. وتحديد العلاقة بين جودة الحياة والوظيفة العائلية، والخصائص الإجتماعية السكانية.

طرق البحث: ضمت هذه الدر اسة المقطعية ه ا من الآباء لأطفال مصابين بأي نوع من أنواع اضطر اب قصور الانتباه وفرط الحركة، وقد اختيروا

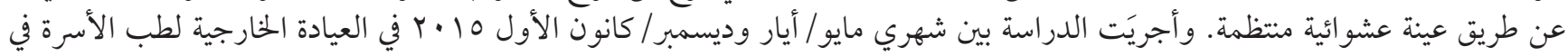

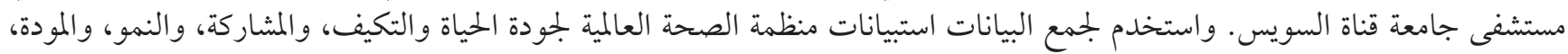
و القرار.

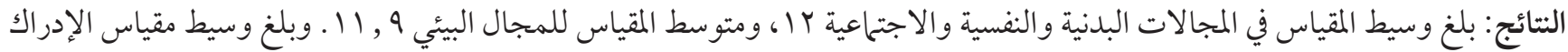

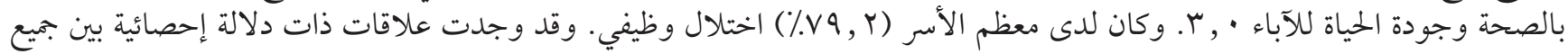

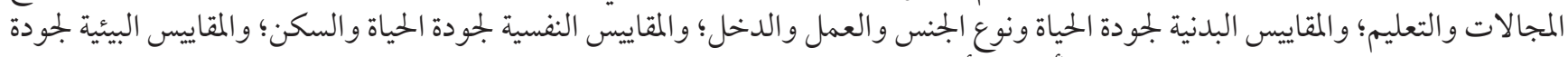

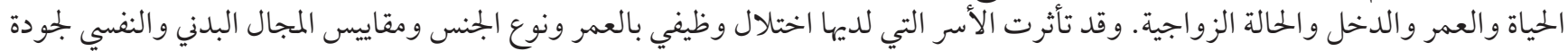
الحياة لدى الآباء.

الاستنتاجات: آباء الأطفال المصابين بقصور الانتباه وفرط الحركة كان لديهم جودة حياة متوسطة. وكان لدى معظم الآباء اختلال وظيفي عائلي.

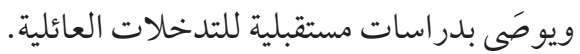

\section{References}

1. Rader R, McCauley L, Callen EC. Current strategies in the diagnosis and treatment of childhood attention-deficit/hyperactivity disorder. Am Fam Physician. 2009 Apr 15;79(8):657-65. PMID:19405409

2. Vaidya CJ. Neurodevelopmental abnormalities in ADHD. Curr Top Behav Neurosci. 2012;9:49-66. https://doi. org/10.1007/7854_2011_138 PMID:21541845

3. Felt BT, Biermann B, Christner JG, Kochhar P, Harrison RV. Diagnosis and management of ADHD in children. Am Fam Physician. 2014 Oct 1;90(7):456-64. PMID:25369623

4. Alhraiwil NJ, Ali A, Househ MS, Al-Shehri AM, El-Metwally AA. Systematic review of the epidemiology of attention deficit hyperactivity disorder in Arab countries. Neurosciences (Riyadh). 2015 Apr;20(2):137-44. https://doi.org/10.17712/nsj.2015.2.20140678 PMID:25864066

5. Aboul-ata MA, Amin FA. The prevalence of ADHD in Fayoum City (Egypt) among school-age children: depending on a DSM-5based rating scale. J Atten Disord. 2018 Jan;22(2):127-133. https://doi.org/10.1177/1087054715576917 PMID:25814429

6. WHOQOL Group. The World Health Organization Quality of Life assessment (WHOQOL): position paper from the World Health Organization. Soc Sci Med. 1995 Nov;41(10):1403-9. https://doi.org/10.1016/0277-9536(95)oo112-K PMID:8560308

7. World Health Organization Division of Mental Health and Prevention of Substance Abuse. Programme on Mental Health. WHOQOL User Manual. Geneva: World Health Organization; 1998 (WHO/HIS/HSI Rev. 2012. 03, http://apps.who.int/iris/bitstream/10665/77932/1/WHO_HIS_HSI_Rev.2012.03_eng.pdf, accessed 26 March 2018)

8. Xiang YT, Luk ES, Lai KY. Quality of life in parents of children with attention-deficit-hyperactivity disorder in Hong Kong. Aust N Z J Psychiatry. 2009 Aug;43(8):731-8. https://doi.org/10.1080/00048670903001968 PMID:19629794

9. Fleck K, Jacob C, Philipsen A, Matthies S, Graf E, Hennighausen K, et al. Child impact on family functioning: a multivariate analysis in multiplex families with children and mothers both affected by attention-deficit/hyperactivity disorder (ADHD). Atten 
Defic Hyperact Disord. 2015 Sep;7(3):211-23. https://doi.org/10.1007/s12402-014-0164-8 PMID:25588606

10. Foley M. A comparison of family adversity and family dysfunction in families of children with attention deficit hyperactivity disorder (ADHD) and families of children without ADHD. J Spec Pediatr Nurs. 2011 Jan;16(1):39-49. https://doi.org/10.1111/j.17446155.2010.00269.x PMID:21294834

11. Dawson B, Trapp R. Basic \& clinical biostatistics. 4th edition. McGraw-Hill; 2004.

12. [Arabic version of WHOQOL-BREF Questionnaire for researchers 1997] (http://site.iugaza.edu.ps/ajedi/files/2010/o2/Arabic WHOQOL_Questionnaire_For_researchers.pdf, accessed 26 March 2018) (in Arabic).

13. Ohaeri JU, Awadalla AW. The reliability and validity of the short version of the WHO Quality of Life Instrument in an Arab general population. Ann Saudi Med. 2009 Mar-Apr;29(2):98-104. https://doi.org/10.4103/0256-4947.51790 PMID:19318760

14. Chaves C, Amaral OP, Nelas P, Coutinhoa EC, Dionisio RM. Assessment of family functionality among the elderly with chronic illness. Eur J Couns Psychol. 2013;2(2):139-44. https://doi.org/10.5964/ejcop.v2i2.31

15. Ismail M. Studying family function in two Arabic countries-Egypt and United Arab Emirates. Med J Cairo Univ. 2008;76(3):41-8.

16. Kim Y, Kim B, Chang JS, Kim BN, Cho SC, Hwang JW. Parental quality of life and depressive mood following methylphenidate treatment of children with attention-deficit hyperactivity disorder. Psychiatry Clin Neurosci. 2014 Jul;68(7):506-14. https://doi. org/10.1111/pcn.12155 PMID:24417707

17. Hadi N, Saghebi A, Ghanizadeh A, Montazeri A. Assessment of health-related quality of life in mothers of children with attention-deficit hyperactivity disorder (ADHD). Shiraz E Med J. 2013;14(2): 91-101. emedicalj.com/28203.pdf.

18. Moen ØL, Hedelin B, Hall-Lord ML. Parental perception of family functioning in everyday life with a child with ADHD. Scand J Public Health. 2015 Feb;43(1):10-7. https://doi.org/10.1177/1403494814559803 PMID:25420708

19. Mohammadi MR, Farokhzadi F, Alipour A, Rostami R, Dehestani M, Salmanian M. Marital satisfaction amongst parents of children with attention deficit hyperactivity disorder and normal children. Iran J Psychiatry. 2012 Summer;7(3):120-5. PMID:23139693

20. Pour EM, Kasaei F. Family functioning in children with attention-deficit/hyperactivity disorder. Procedia Soc Behav Sci. 2013;84:1864-5. https://doi.org/10.1016/j.sbspro.2013.07.049 